\title{
OUTLINING PRECISION BOUNDARIES AMONG AREAS WITH DIFFERENT VARIABILITY STANDARDS USING MAGNETIC SUSCEPTIBILITY AND GEOMORPHIC SURFACES
}

\section{SAMMY S. R. MATIAS ${ }^{1}$; JOSÉ MARQUES JÚNIOR ${ }^{2}$, DIEGO S. SIQUEIRA ${ }^{2}$; GENER T. PEREIRA ${ }^{2}$}

\begin{abstract}
There is an increasing demand for detailed maps that represent in a simplified way the knowledge of the variability of a particular area or region maps. The objective was to outline precision boundaries among areas with different accuracy variability standards using magnetic susceptibility and geomorphic surfaces. The study was conducted in an area of 110 ha, which identified three compartment landscapes based on the geomorphic surfaces model. To determinate $\mathrm{pH}$, organic matter, phosphorus, potassium and magnesium, the total sand and clay, 514 soil samples were collected at depths of $0-0.20 \mathrm{~m}$ and $0.60-0.80 \mathrm{~m}$. The sum of base, cationic exchange capacity and base saturation were calculated and the magnetic susceptibility was evaluated in the laboratory using a system based on a balance of analytical precision method. Geomorphic surfaces identification allowed setting specific management areas (locations with maximum homogeneity of soil attributes). The map of spatial variability of magnetic susceptibility can be used to validate the precise boundaries among geomorphic surfaces identified in the field and infer the variability of clay content and soil base saturation.
\end{abstract}

KEYWORDS: detailed mapping, pedometrics, accuracy boundaries.

\section{DELINEAMENTO DE LIMITES DE PRECISÃO ENTRE ÁREAS COM DIFERETES PADRÕES DE VARIABILIDADE UTILIZANDO SUSCETIBILIDADE MAGNÉTICA E SUPERFÍCIES GEOMÓRFICAS}

RESUMO: Existe uma demanda cada vez maior por mapas detalhados que representem de maneira simplificada o conhecimento da variabilidade de determinada área ou região. O objetivo do trabalho foi delinear limites de precisão entre áreas com diferentes padrões de variabilidade utilizando suscetibilidade magnética e superfícies geomórficas. O trabalho foi realizado em uma área de 110 ha, onde se identificaram três compartimentos de paisagem com base no modelo de superfícies geomórficas. Foram coletadas 514 amostras de solo nas profundidades de 0-0,20 m e 0,60-0,80 m, para a determinação de $\mathrm{pH}$, matéria orgânica, fósforo, potássio e magnésio, areia total e argila. A soma de base, capacidade de troca catiônica e saturação por bases foram calculadas. A suscetibilidade magnética foi avaliada em laboratório, utilizando-se de um método baseado em uma balança de precisão analítica. A identificação das superfícies geomórficas permitiu o reconhecimento de áreas específicas de manejo (locais com máxima homogeneidade dos atributos do solo). O mapa de variabilidade espacial da suscetibilidade magnética pode ser utilizado para validar com precisão os limites entre as superfícies geomórficas identificadas no campo e inferir a variabilidade do teor de argila e saturação por base do solo.

PALAVRAS-CHAVE: mapeamento detalhado, pedometria, limites de precisão.

\footnotetext{
1 Eng. Agrônomo, Prof. Doutor, Departamento de Solos, Universidade Estadual do Piauí, Prof Joaquina Nogueira Oliveira, s/n, Aeroporto, CEP 64980-000, Corrente-PI, Brasil. Fone: (89) 3573-2093. E-mail: ymmsa2001@yahoo.com.br

2 Eng. Agrônomo, Prof. Doutor, Departamento de Solos, Universidade Estadual Paulista Júlio de Mesquita Filho, Faculdade de Ciências Agrárias e Veterinárias de Jaboticabal, Via de Acesso Prof. Paulo Donato Castelanne, s/n, Zona Rural, CEP 14884900, Jaboticabal-SP, Brasil. Fone: (16) 3209-2601. Fax: (16) 3209-2673. E- mail: marques@fcav.unesp.br,

diego_silvasiqueira@yahoo.com.br, genertp@fcav.unesp.br

Recebido pelo Conselho Editorial em: 3-9-2012
}

Aprovado pelo Conselho Editorial em: 23-2-2014 


\section{INTRODUCTION}

The demand for detailed maps that represent in a simplified way the knowledge of the variability of a particular area or region is increasing. These maps provide information that can be used to mark the sustainable production, enabling the development according to current research by providing information that enables the reduction of the overall impacts through indicators in the use and occupation of land (ROCKSTROM et al., 2009).

Among the management tools for sustainable development, there is the soil map. The characterization and interpretation of soils enable soil and water conservation job and estimated agricultural yield (SANCHEZ et al., 2012). In this case, the landscape model RUHE (1969) and DANIELS et al. (1971) can be applied, allowing the identification by the variability of the chemical, physical and mineralogical soil properties, indicating the best way to work sustainably. The model of geomorphic surface from DANIELS et al. (1971) is widely accepted and has been used inclusively by the North American correlates to identify areas with different characteristics.

In Brazil, as discussed by VIDAL-TORRADO et al. (2005), this type of model, which requires multidisciplinary knowledge, is still largely unexplored, despite its great potential use. Several studies conducted in Brazil (CUNHA et al., 2005; CAMPOS et al., 2007; CAMPOS et al., 2012a; CAMPOS et al., 2012b) demonstrated geomorphic surfaces applicability and its concepts in soil science. CAMPOS et al. (2012b), confirm that different taxonomic classes may present same pattern of soil attributes variability, if they are in same geomorphic surface.

However, the absence of detailed information on soil and its attributes is further aggravated with the lack of experienced soil scientists (mappers) (DEMATTÊ et al., 2007; SANCHEZ et al., 2012). Additionally, there is deficiency in cartographic works and soil taxonomic (Radam Brasil and state survey) compared to new advances in soil knowledge, its attributes, and further studies on variability (CAMPOS et al., 2012a; SANCHEZ et al., 2012).

In order to add information on the mapping in more detailed scales and find a pattern of soil attributes variability that can be used to explain the agricultural production, SANCHEZ et al. (2012) suggest the use of geostatistics. Other authors have associated the use of this numerical classification tool with models of landscape as geomorphic surfaces (CAMPOS et al., 2007; CAMPOS et al., 2012a), terrain forms (SIQUEIRA et al., 2010a; SANCHEZ et al., 2012) and small variations in terrain (SANCHEZ et al., 2009). According to SANCHEZ et al. (2012) the identification of these regions, with maximum homogeneity of soil attributes, named by SIQUEIRA et al. (2010a) as specific areas of management, ensures a more precise location of boundaries among different areas, making possible the transfer of agronomic techniques to similar environments easily and economically.

However, precision and accuracy of these procedures are related to the number of observation points, which increase mapping costs (DEMATTÊ et al., 2007; CAMPOS et al., 2012a). In South America, procedures that require a large number of samples is not widely used due to high cost of soil analysis. Some researchers have used magnetic susceptibility (MS) (SOUZA JR et al., 2010; SIQUEIRA et al., 2010b; SANTOS et al., 2011) in the indirect measurement of physical, chemical and mineralogical soil properties to increase number of collected points, without raising costs and time analysis because they require more complex laboratory tests than others. Thus, the MS shall be used as a pedometer tool to enable variability mapping over large areas, as suggested by SIQUEIRA et al. (2010b). The MS is a mineral characteristic present in rocks and soil, whose magnitude depends on mineral concentration and characteristics such as composition, crystal spatial structure and size (TORRENT et al., 2007; SOUZA JÚNIOR et al., 2010).

Studies involving magnetic susceptibility presented results on boundary settlement among soil classes (SOUZA JÚNIOR et al., 2010 and SANTOS et al., 2011.), correlation with clay content $(\mathrm{r}=0.68, \mathrm{P}<0.01)$, base saturation $(\mathrm{r}=0.75, \mathrm{P}<0.01)$ and hematite content $(\mathrm{r}=0.81, \mathrm{P}<0.01)$ (SIQUEIRA et al., 2010b). What also happen for physical, chemical and mineralogical properties in 
different soil classes (SOUZA JÚNIOR et al., 2010) and identification of different erosion risk potentials (SANTOS et al., 2011). However, according to SIQUEIRA et al. (2010b), SANTOS et al. (2011) and SOUZA JUNIOR et al. (2011) their studies in Brazilian agriculture are still incipient.

Thus, the objective of this study was to delineate accuracy boundaries among areas with different variability patterns using magnetic susceptibility and geomorphic surfaces.

\section{MATERIAL AND METHODS}

The experiment was conducted in an area of 110 ha (Figure 1), cultivated with sugar cane for 35 years, located in the northeast of São Paulo State, in Guariba city. The geographical coordinates are $21^{\circ} 24^{\prime} \mathrm{S}$ and $48^{\circ} 09^{\prime} \mathrm{W}$, with an average altitude of $630 \mathrm{~m}$. The climate, according to Köppen classification, is mesothermal with dry winters (Cwa), temperatures range from $21{ }^{\circ} \mathrm{C}$ to $27{ }^{\circ} \mathrm{C}$, average rainfall of $1,400 \mathrm{~mm}$, with rainfall concentrated between November to February. The terrain is considered flat to slightly undulating, with slopes ranging from 3 to $8 \%$. The geological material in the studied area is related to sandstones originated from Grupo Bauru, Formação Adamantina and basalts from São Bento Group, Formação Serra Geral, and basalt-sandstone reworked equipment (IPT 1981). Local soil map, elaborated by the Sugarcane Technology Center (Centro de Tecnologia Canavieira - CTC), show occurrence of Dystrophic Red Yellow Oxisols with medium texture (DRYL) and Dystrophic Red Oxisols with medium texture (DRL) in a detailed scale of 1: 12,000.

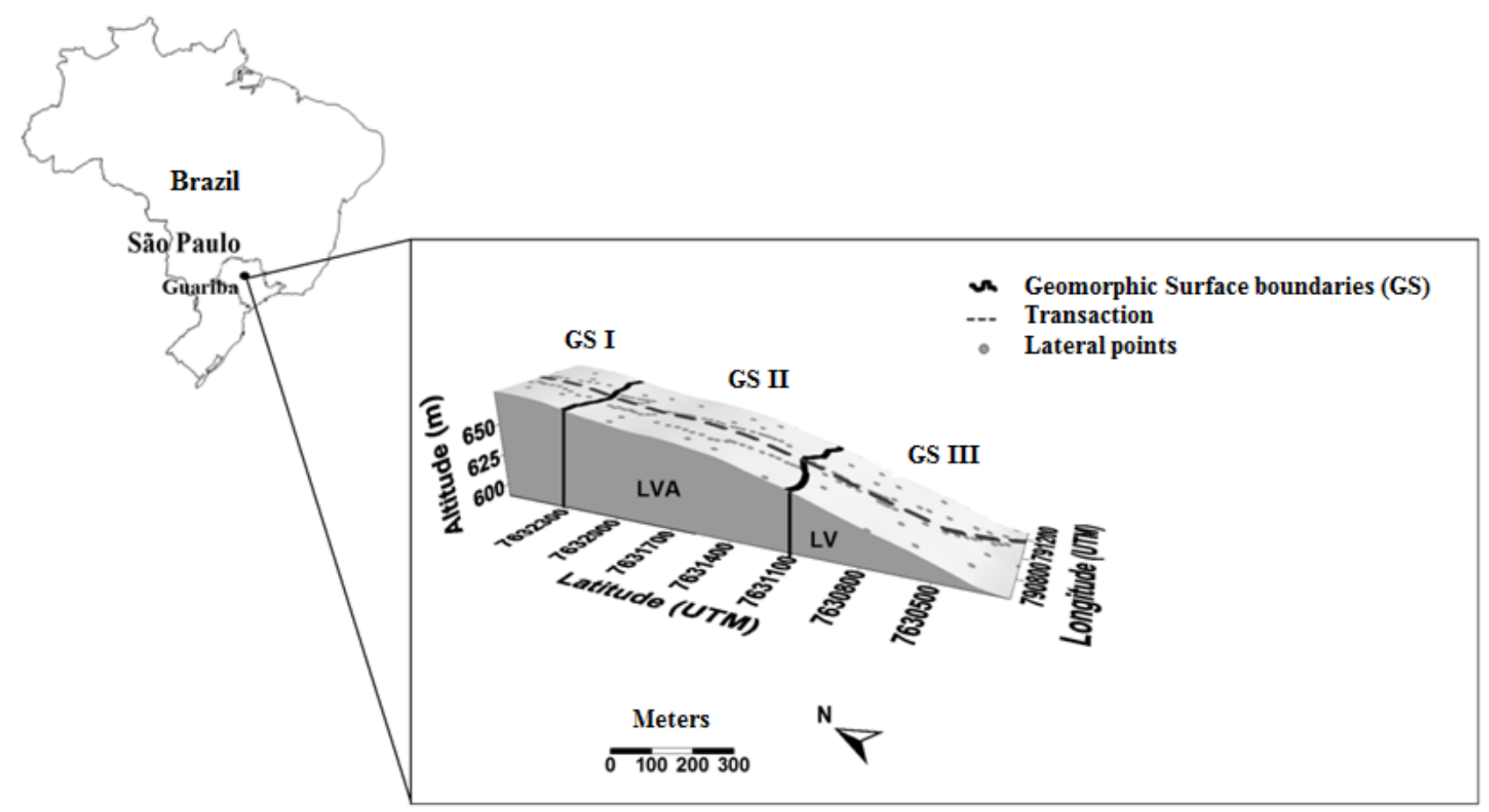

FIGURE 1. Digital elevation model for the studied area and identification of geomorphic surfaces and soils (LVAd = Dystrophic Red Yellow Oxisol; LVd = Red Oxisol both of medium texture).

The geomorphic surfaces were identified and delimited according to criteria proposed by RUHE (1969) and DANIELS et al. (1971) using topographic information (planialtimetric profile), stratigraphic (source material), slope study and careful field observations of changes in terrain slope (Figure 1). The contents of $\mathrm{Fe}_{2} \mathrm{O}_{3}$ of acid-sulfuric attack on the area range from 58 in geomorphic surface I (GS I), 59 in geomorphic surface II (GS II) to $76 \mathrm{~g} \mathrm{~kg}^{-1}$ in geomorphic surface III (GS III). From the top to the bottom slope, soils present, in Munsell chart, color with hue 2.5 to $5 Y$. Iron content $\left(\mathrm{Fe}_{2} \mathrm{O}_{3}\right)$ variation in the area is $48.1 \mathrm{~g} \mathrm{~kg}^{-1}$ from the top to $54.4 \mathrm{~g} \mathrm{~kg}^{-1}$ at foothill. It is 
emphasized in GS III the presence of mudstone, a sedimentary rock formed by cementation of silt and clay sized-particle together at varied ratios.

A 2,700 meter transect was performed from the slope top throughout ridge up to foothill towards gentle slope way. Soil samples were collected on transect each 25 meters. To evaluate bidimensionality principle of geomorphic surfaces, soil samples were collected randomly beside transect (DANIELS et al., 1971). Bi-dimensionality principle is based on the concept that although boundaries among geomorphic surfaces are identified based on a single direction, the transect direction, these limits are continuous across landscape and perpendicular to the main transect. Randomly at $0-0.20 \mathrm{~m}$ and $0.60-0.80 \mathrm{~m}$ depths, a number of 204 samples were collected at the transect and 310 samples on its side (58, 148 and 104 samples in GS I, GS II and GS III, respectively) (Figure 1).

Samples were subjected to particle size analysis using a $1 \mathrm{~N} \mathrm{NaOH}$ solution as a chemical dispersant and mechanical stirring apparatus at low speed for $16 \mathrm{~h}$, following method proposed by EMBRAPA (1997). The clay (CLA), total sand (TS) and silt were determined by pipette methods. The $\mathrm{pH}$ was potentiometrically determined using a soil ratio $1: 2.5$ in $0.01 \mathrm{~mol} \mathrm{~L}^{-1} \mathrm{CaCl}_{2}$. Organic matter content (OM), phosphorus (P), potassium (K), calcium (Ca) and magnesium (Mg) was determined according to the method proposed by RAIJ et al. (2001). Based on the results of chemical analyzes, we calculated the sum of bases (SB), cationic exchange capacity (CEC), and base saturation (V\%).

Magnetic susceptibility value (MS) " $\chi$ " was measured in the laboratory for all collected samples, using an analytical balance according to CANO et al. (2008) method, and fitted to soil MS reading by SIQUEIRA et al. (2010b). Equipment consists of an analytical balance, one magnet, and one magnet and sample support. Minerals with magnetic expression in soil sample and magnet interaction promotes on the balance a weight force. Then, this weight is converted into MS using a standard curve.

Descriptive statistics such as average, median and kurtosis, skewness and variation coefficients were performed. For a descriptive data analysis, the SAS (STATISTICAL ANALYSIS SYSTEM, 2007) software was used. The Pearson correlation was performed in MINITAB (MINITAB Release, 2000) software.

The analysis of spatial dependence was made by means of geostatistics, according to WEBSTER (1973). All semivariogram results were obtained through $\mathrm{GS}^{+}$software (ROBERTSON, 2008). The $R^{2}$ (coefficient of determination) close to 1 and regression parameters of crossvalidation (angular coefficient close to 1 and intercept close to 0 ) was considered when there was doubt in more than one model for the same semivariogram. Interpolation was done using kriging based on the adjusted semivariogram models. The kriging maps, also called variability maps were made using Surfer software (GOLDEN SOFTWARE INC., 2000).

\section{RESULTS AND DISCUSSION}

The highest values of MS were obtained from GS III (Table 1). This is due to the higher iron content $\left(\mathrm{Fe}_{2} \mathrm{O}_{3}\right)$ in this compartment. According to SOUZA JÚNIOR et al. (2010) and TORRENT et al. (2010) there is a positive relationship between iron content and MS in Brazilian Oxisols, because it reflects the mineral composition of these soils. 
TABLE 1. Descriptive statistics of chemical, physical and magnetic susceptibility at $0-0.20 \mathrm{~m}$ and 0.60-0.80 m depths.

\begin{tabular}{|c|c|c|c|c|c|c|c|c|c|}
\hline \multirow[t]{2}{*}{ Statistics } & \multirow[t]{2}{*}{ Depth (m) } & \multicolumn{5}{|c|}{----------- Chemical attributes-------- } & \multicolumn{3}{|c|}{ Physical attributes } \\
\hline & & $\mathrm{pH}$ & $\mathrm{OM}$ & SB & CEC & $\mathrm{V}$ & TS & CLA & MS \\
\hline & & $\mathrm{CaCl}_{2}$ & $\mathrm{~g} \mathrm{dm}^{-3}$ & \multicolumn{2}{|c|}{ 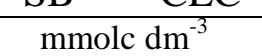 } & $\%$ & \multicolumn{3}{|c|}{$---\mathrm{g} \mathrm{kg}^{-1}$--- $10^{-6} \mathrm{~m}^{3} \mathrm{~kg}^{-1}$} \\
\hline \multicolumn{10}{|c|}{ GS I } \\
\hline \multirow{2}{*}{ Average } & $0.00-0.20$ & 5.5 & 20.8 & 61.4 & 81.3 & 74 & 586 & 368 & 2.7 \\
\hline & $0.60-0.80$ & 4.1 & 11.3 & 11.3 & 59.6 & 20 & 548 & 419 & 2.3 \\
\hline \multirow[t]{2}{*}{ Median } & $0.00-0.20$ & 5.6 & 20.0 & 56.95 & 81.4 & 73 & 596 & 367 & 2.6 \\
\hline & $0.60-0.80$ & 4.1 & 11.5 & 11.5 & 57.8 & 20 & 552 & 418 & 2.3 \\
\hline \multirow[t]{2}{*}{ Skewness } & $0.00-0$ & -0.79 & 0.75 & 0.18 & -0.10 & -0.54 & -0.04 & 0.77 & 0.59 \\
\hline & $0.60-0.80$ & 1.85 & -1.05 & 0.63 & 0.86 & 0.68 & -0.01 & -0.19 & 0.93 \\
\hline \multirow[t]{2}{*}{ Kurtosis } & $0.00-0.20$ & 0.49 & 3.95 & 0.01 & 0.01 & -0.17 & -0.39 & 0.98 & -0.09 \\
\hline & 0.60 & 3.00 & 4.75 & 0.05 & 0.90 & 0.11 & -0.52 & -0.53 & 1.08 \\
\hline \multirow[t]{2}{*}{ VC\% } & $0.00-0.20$ & 8.31 & 27.86 & 34.08 & 15.14 & 13.18 & 2.78 & 4.20 & 11.08 \\
\hline & 0.60 & 8.48 & 22.96 & 28.67 & 13.68 & 31.40 & 3.45 & 3.99 & 9.18 \\
\hline \multicolumn{10}{|c|}{ GS II } \\
\hline \multirow[t]{2}{*}{ Average } & $0.00-0.20$ & 5.1 & 19.3 & 38.4 & 68.0 & 57 & 612 & 358 & 4.4 \\
\hline & $0.60-0.80$ & 4.4 & 9.4 & 14.0 & 52.7 & 28 & 546 & 424 & 4.3 \\
\hline \multirow{2}{*}{ Median } & $0.00-0.20$ & 5.2 & 19.0 & 38.2 & 67.75 & 57 & 612 & 348 & 3.5 \\
\hline & 0.6 & 4.4 & 9.0 & 13.6 & 52.95 & 27 & 554 & 418 & 3.3 \\
\hline \multirow[t]{2}{*}{ Skewness } & $0.00-0.20$ & 0.22 & 0.33 & 0.60 & 0.61 & -0.15 & -0.08 & 0.17 & 0.88 \\
\hline & $0.60-0.80$ & 0.27 & 0.33 & 0.59 & -0.35 & 0.39 & -0.59 & 0.49 & 0.90 \\
\hline \multirow[t]{2}{*}{ Kurtosis } & $0.00-0.20$ & 0.09 & -0.48 & 0.23 & 0.11 & -0.26 & 0.20 & 0.42 & 0.24 \\
\hline & 0.60 & -0.90 & -0.37 & -0.11 & 0.02 & -0.72 & 1.05 & 0.80 & -0.01 \\
\hline \multirow[t]{2}{*}{$\mathrm{VC} \%$} & $0.00-0.20$ & 9.51 & 15.53 & 38.28 & 14.05 & 28.26 & 7.71 & 11.88 & 48.00 \\
\hline & $0.60-0.80$ & 9.24 & 16.74 & 49.40 & 13.35 & 50.63 & 8.27 & 10.31 & 48.91 \\
\hline \multicolumn{10}{|c|}{ GS III } \\
\hline \multirow[t]{2}{*}{ Average } & $0.00-0.20$ & 5.0 & 23.0 & 38.7 & 73.3 & 52 & 520 & 437 & 7.7 \\
\hline & $0.60-0.80$ & 4.6 & 10.4 & 17.2 & 51.0 & 33 & 452 & 509 & 7.4 \\
\hline \multirow[t]{2}{*}{ Median } & $0.00-0.20$ & 5.0 & 23.0 & 38.1 & 74.0 & 53 & 528 & 429 & 8.0 \\
\hline & $0.60-0.80$ & 4.6 & 10.0 & 16.0 & 50.9 & 34 & 451 & 512 & 7.4 \\
\hline \multirow[t]{2}{*}{ Skewness } & $0.00-0.20$ & 0.80 & 0.13 & 0.33 & -0.52 & -0.10 & -0.59 & 0.38 & 0.23 \\
\hline & $0.60-0.80$ & 0.42 & 0.58 & 0.62 & 0.24 & 0.02 & -0.31 & 0.07 & 0.02 \\
\hline \multirow[t]{2}{*}{ Kurtosis } & $0.00-0.20$ & -0.53 & -0.03 & -0.48 & 2.91 & -0.45 & 0.35 & 0.00 & 0.23 \\
\hline & $0.60-0.80$ & 0.48 & 0.04 & -0.21 & 0.31 & -1.16 & -0.20 & -0.49 & 0.24 \\
\hline \multirow[t]{2}{*}{$\mathrm{VC} \%$} & $0.00-0.20$ & 7.12 & 18.15 & 30.59 & 13.42 & 23.81 & 17.6 & 18.69 & 32.43 \\
\hline & $0.60-0.80$ & 9.92 & 20.63 & 50.13 & 13.53 & 44.94 & 18.85 & 14.26 & 39.11 \\
\hline
\end{tabular}

pH in $\mathrm{CaCl}_{2}$; organic matter (OM); sum of bases (SB); cation exchange capacity (CTC); base saturation (V\%); total sand (TS), clay (CLA) and magnetic susceptibility (MS). geomorphic surface (GS) I, II and III.

Average and median values are close, which indicates that data normality. Additionally, skewness coefficient close to zero and kurtosis close to one confirm these results. According to ROSA FILHO et al. (2009), when any variable has a normal statistical frequency distribution, the most suitable central tendency measurement to represent them should be the average; in contrast, it will be represented by the median or geometric average, if it is lognormal type.

In Table 1, it was found that all attributes can be represented by the average because they have shown the same normal frequency distribution (ROSA FILHO et al., 2009), confirmed by skewness and kurtosis coefficients. In general, by normal frequency distribution, data were consistent with the results observed by CAMPOS et al. (2009); SANCHEZ et al. (2009); SIQUEIRA et al. (2010a) and MONTANARI et al. (2012), who studied spatial variability by means of soil attributes. BURROUGH \& MCDONNELL (2000) and YAMAMOTO \& LANDIM (2013), 
emphasize that normality is not required to perform geostatistical analysis; however, very elongated tails, are a pre-clue of trend or data have to be transformed to ensure the variogram model best fit.

Variation coefficient estimate can be used to evaluate attribute variability (CAMPOS et al., 2009; SANCHEZ et al., 2009; SIQUEIRA et al., 2010a; SANCHEZ et al., 2012.) and to determine minimum number of samples (OBI \& OGUNKUNLE, 2009; MONTANARI et al., 2012). However, it does not allow assessing attribute spatial dependence and accuracy boundary identification among different variable classes. High VC values can be considered a first indicator of data heterogeneity, assisting in variabillity inference at many places. In turn, soil property changes might be classified into low (VC $\leq 12 \%)$, medium $(12 \%<\mathrm{VC} \leq 60 \%)$ and high (VC $\geq 60 \%)$, as variation proposed by WARRICK \& NIELSEN (1980).

Attributes such as SB, CEC, V\% had medium VC at the two depths. Lower and higher VC trend of geomorphic surfaces I (GS I) to GS III varied from 13.42\% to 50.36\% (Table 1). Indicating that GS I has less variability (more homogeneous) than GS III. According to that, CAMPOS et al. (2007) and SANTOS et al. (2011) found similar results in studies of soil-landscape relation. Variability of soil chemical properties is associated to both factor interactions of soil formation and processes, and management practices (CAMPOS et al., 2009; OBI \& OGUNKUNLE, 2009; SANCHEZ et al., 2009; SIQUEIRA et al., 2010b; SANTOS et al., 2011).

Nonetheless, we note that the area homogeneity is more related to geomorphic surfaces model, in which the most weathered surface (GS I) had lower VC (less variability) than the least weathered one (GS III), being similar to results of CAMPOS et al. (2007), SANTOS et al. (2011), CAMPOS et al. (2012b). Despite the good applicability in soil science field, geomorphological models are underutilized. According to RUHE (1969) and DANIELS et al. (1971), the geomorphic surfaces are conceptually related to slope weathering rate, as shown by CUNHA et al. (2005).

It was also observed that $\mathrm{pH}$, TS and CLA attributes presented low variation, except for TS and CLA at GS III, which was classified as medium (Table 1). Probably, the greatest variability of texture attributes on this surface is due to less erosion process occurred, according to geomorphic surface concept. Our results are in agreement with CAMPOS et al. (2007) and CAMPOS et al. (2012b), who identified boundaries of geomorphic surfaces by means of physical attributes finding lower values of VC in GS I. These results confirm the landscape model proposed by RUHE (1969) and DANIELS et al. (1971), where the soil is the age of the surfaces on which they are located. Thus, Red Yellow Oxisols in GS I is older than the Red Oxisols that occurs in GS III.

Correlation between soil attributes and MS was performed at both depths (Table 2). MS had negative correlation with $\mathrm{pH}, \mathrm{SB}$ and $\mathrm{V} \%$ chemical properties and positive with $\mathrm{OM}$ at $0-0.20 \mathrm{~m}$ depth; but positive correlation with $\mathrm{pH}$; SB; CEC and V\% at 0.60-0.80 m depth. Regarding the texture attributes, both layers results were the same, being negative for total sand (TS) and positive for clay content (CLA). SIQUEIRA et al. (2010b) also found a negative correlation with base saturation and positive with clay content at 0-0.20 m depth.

These results indicate that minerals with great magnetic expression in the studied area are found in clay fraction. Despite soil magnetic parameters show great potential for application in areas with high clay content (SOUZA JÚNIOR et al., 2010) and total iron $\left(\mathrm{Fe}_{2} \mathrm{O}_{3}\right)$ (TORRENT et al., 2010). SIQUEIRA et al. (2010b), SANTOS et al. (2011) show that MS also has application in soils with low iron content $\left(<4 \% \mathrm{Fe}_{2} \mathrm{O}_{3}\right)$ and medium texture.

Soil iron content is also important in classification, as they help to determine great groups of ferric character and family to other mineral contents. In the present study, soil is classified into hypoferric range (low $\mathrm{Fe}_{2} \mathrm{O}_{3}$ content $<80 \mathrm{~g} \mathrm{~kg}^{-1}$ ). Thus, in addition to being an alternative pedometer tool for predicting other soil attributes, MS can assist in better detail of environments with different iron levels, suggesting subdivisions for iron ranges already recommended, especially for soils with low content. 
TABLE 2. Pearson linear correlation among chemical, physical and magnetic susceptibility (MS) at 0.00-0.20 $\mathrm{m}$ and 0.60-0.80 $\mathrm{m}$ depths.

\begin{tabular}{|c|c|c|c|c|c|c|c|}
\hline & $\mathrm{pH}$ in $\mathrm{CaCl}_{2}$ & $\mathrm{OM}$ & SB & CEC & $\mathrm{V} \%$ & TS & CLAY \\
\hline \multirow{4}{*}{ MS } & \multicolumn{7}{|c|}{$0.00-0.20 \mathrm{~m}$ depth } \\
\hline & $-0.16 *$ & $0.22 * *$ & $-0.12 *$ & -0.00 & $-0.16 * *$ & $-0.74^{* *}$ & $0.71 * *$ \\
\hline & \multicolumn{7}{|c|}{$0.60-0.80 \mathrm{~m}$ depth } \\
\hline & $0.48 * *$ & 0.05 & $0.36^{* *}$ & $0.15^{*}$ & $0.41^{* *}$ & $-0.75 * *$ & $0.72 * *$ \\
\hline
\end{tabular}

* and ** significant at 5 and $1 \%(\mathrm{P}<0,05$ e $\mathrm{P}<0,01)$ probability by $\mathrm{F}$ test, respectively.

These results demonstrate that MS can be used as an auxiliary tool to quantify chemical and texture attributes of soil across landscape. Whereas sampling and laboratory analysis are some of the most costly steps and can hinder variability studies and application, magnetic susceptibility data can be used in mathematical models, called pedotransfering functions to estimate clay and total sand contents with full accuracy up to 70\% (SIQUEIRA et al., 2010b). Studies such as TORRENT et al. (2007); SIQUEIRA et al. (2010a) and SOUZA JÚNIOR et al. (2010) have confirmed predictive potential of MS in relation to other soil attributes (physical, chemical and mineralogical) at different soil types.

Models fitted to chemical, granulometric and MS data were exponential for $\mathrm{pH}$, CEC and $\mathrm{V}$ (\%); spherical for SB, TS and CLA; and Gaussian for OM and MS, at 0-0.20 m depth (Table 3). These results are in agreement with TORRENT et al. (2007), SANTOS et al. (2011); SANCHEZ et al. (2012) and CAMPOS et al. (2012b), who examined the soil landscape relation in different soil and climatic situations and found similar models. Regarding 0.60-0.80 m depth, models fitted to attribute data were: exponential for SB; spherical for $\mathrm{pH}$, OM, CEC, TS and CLA; Gaussian for V\% and MS. CAMPOS et al. (2007) and CAMPOS et al. (2012b), who studied landscape position effect on chemical and texture attribute distribution, obtained similar results.

It was observed that all variables at both depths had spatial dependence, in which spherical model was predominant, indicating an abrupt transition between compartments identified in field with strong influence of source material. In contrary, exponential and Gaussian models feature a less abrupt and smoother transition between surfaces, respectively. Soil property spatial variability covariates from soil formation factors and processes (TORRENT et al., 2007; SOUZA JÚNIOR et al., 2010). Since the studied area lies over a sandstone-basalt transition with mudstone intrusion, the attribute contents, especially grain size, show abrupt transition, which is best characterized by spherical model.

Regarding nugget effect $\left(\mathrm{C}_{0}\right)$, it is observed that the highest values were obtained for the following variables SB (109.80); V\% (102.10) at 0-0.20 m depth; and V\% (114) at 0.60-0.80 m. The lowest values were obtained for MS; $\mathrm{pH}$; OM; TS and CLA soils for both depths. According to CAMPOS et al. (2009) and SIQUEIRA et al. (2010a), the nugget effect $\left(C_{0}\right)$ explains absence of variation on data, possibly due to measurement errors or variations of attributes that cannot be detected at sample scale or when area is highly homogeneous, in which can represented by average .

Sill $\left[\mathrm{C}_{0} /\left(\mathrm{C}_{0}+\mathrm{C} 1\right)\right]$ is the ratio that indicates spatial dependence degree of variables, showed that physical and chemical properties had a moderate degree at both depths while MS presented strong spatial dependence by CAMBARDELLA et al. (1994) classification. Thus, distribution of chemical, grain size and MS along space are not random, since all showed moderate and strong values for spatial dependence. This demonstrates that the adjusted semivariograms explain most of the data variance in field. Other studies have also found moderate spatial dependence for soil attributes (CAMPOS et al., 2007; SANCHEZ et al., 2012; CAMPOS et al., 2012b) and strong for MS (SANTOS et al., 2011).

Attributes with strong spatial dependence usually covariate from soil formation factors and processes (TORRENT et al., 2007; SOUSA JUNIOR et al., 2010) being considered pedoenvironmental indicators. Since these factors and processes are specific to each site, 
susceptibility can be a promising tool in mapping these locations, mainly in tropical soils, for presenting large variations in magnetic properties due to the factors and processes.

Regarding range, it was found that the studied attributes have different behaviors at both depths (0-0.20 $\mathrm{m}$ and 0.60-0.80 $\mathrm{m}$ ) (Table 3), and showed that at 0.60-0.80 $\mathrm{m}$, in general, higher ranges are observed except for OM and MS, indicating greater spatial distribution continuity is homogeneous attributes. Disagreeing with those obtained by CAMPOS et al. (2007); CAMPOS et al. (2012b) and SANCHEZ et al. (2012), who found the greatest range for chemical attributes found at 0-0.20 m layer, which was justified by a homogeneous handling at this depth.

TABLE 3. Semivariogram model parameters adjusted for $\mathrm{pH}\left(\mathrm{CaCl}_{2}\right)$, organic matter (OM), sum of bases (SB), cation exchange capacity (CEC), base saturation (V\%), total sand (TS), clay (CLA) and magnetic susceptibility (MS) at the studied depths.

\begin{tabular}{|c|c|c|c|c|c|c|c|c|}
\hline \multirow[b]{2}{*}{ Variables } & \multirow[b]{2}{*}{ Model } & \multirow[b]{2}{*}{$\mathrm{C}_{\mathbf{0}}$} & \multirow[b]{2}{*}{$\mathbf{C}_{0}+\mathbf{C}_{1}$} & \multirow[b]{2}{*}{ SDD } & \multirow{2}{*}{$\begin{array}{c}\text { Range } \\
\text { (m) }\end{array}$} & \multirow[b]{2}{*}{$\mathbf{R}^{2}$} & \multicolumn{2}{|c|}{ CVRC } \\
\hline & & & & & & & $\mathbf{b}$ & $\mathbf{A}$ \\
\hline \multicolumn{9}{|c|}{$0.00-0.20 \mathrm{~m}$ depth } \\
\hline $\mathrm{pH}\left(\mathrm{CaCl}_{2}\right)$ & Exponential & 0.10 & 0.21 & 49.52 & 480 & 0.90 & 0.89 & 0.55 \\
\hline OM & Gaussian & 7.55 & 18.48 & 40.85 & 1692 & 0.95 & 0.94 & 1.14 \\
\hline SB & Spherical & 109.80 & 219.70 & 49.98 & 533 & 0.88 & 0.99 & 0.69 \\
\hline CEC & Exponential & 52.50 & 105.10 & 49.95 & 972 & 0.95 & 1.00 & 0.07 \\
\hline $\mathrm{V}$ & Exponential & 102.10 & 223.20 & 45.74 & 456 & 0.84 & 0.99 & 0.39 \\
\hline TS & Spherical & 13.94 & 30.92 & 45.08 & 1233 & 0.54 & 1.00 & -0.17 \\
\hline CLA & Spherical & 9.61 & 21.12 & 45.50 & 930 & 0.93 & 1.00 & -1.63 \\
\hline MS & Gaussian & 0.0002 & 0.001 & 20.00 & 1881 & 0.97 & 0.98 & 0.00 \\
\hline \multicolumn{9}{|c|}{$0.60-0.80 \mathrm{~m}$ depth } \\
\hline $\mathrm{pH}\left(\mathrm{CaCl}_{2}\right)$ & Spherical & 0.09 & 0.19 & 49.74 & 891 & 0.95 & 0.95 & 0.23 \\
\hline $\mathrm{OM}$ & Spherical & 1.56 & 3.22 & 48.65 & 1011 & 0.95 & 1.00 & -0.16 \\
\hline SB & Exponential & 30.35 & 60.71 & 49.99 & 780 & 0.87 & 0.98 & 0.49 \\
\hline CEC & Spherical & 30.74 & 61.49 & 49.99 & 1240 & 0.94 & 0.95 & 2.54 \\
\hline $\mathrm{V}$ & Gaussian & 114.00 & 234.00 & 48.72 & 621 & 0.96 & 1.00 & 0.39 \\
\hline TS & Spherical & 12.56 & 30.24 & 41.53 & 1599 & 0.78 & 0.93 & 3.67 \\
\hline CLA & Spherical & 15.70 & 57.21 & 27.44 & 2381 & 0.88 & 0.91 & 3.64 \\
\hline MS & Gaussian & 0.0002 & 0.001 & 20.00 & 1423 & 0.92 & 0.98 & 0.00 \\
\hline
\end{tabular}

$\mathrm{C}_{0}=$ nugget effect; $\mathrm{C}_{0}+\mathrm{C}_{1}=$ sill; $\mathrm{R}^{2}=$ model determination coefficient; $\mathrm{SDD}\left(\mathrm{C}_{0} /\left(\mathrm{C}_{0}+\mathrm{C}\right) * 100\right)=$ spatial dependence degree, being the nugget efect $=100 \%$ of sill. In which is moderate between 25 and $75 \%$; weak $>75 \%$; strong $\leq 25 \%$; CRVC = cross validation regression coefficient; $a$ = intercept; $b$ = angular coefficient.

Observing range values of $1881 \mathrm{~m}$ and $1423 \mathrm{~m}$ for MS at 0-0.20 $\mathrm{m}$ and $0.60-0.80 \mathrm{~m}$ depths, respectively; we noticed close values, indicating representativeness of proposed models. Attributes that had the nearest MS range were OM and total sand at 0.0-0.20 m depth, and OM, CEC, and total sand at 0.60-0.80 m. SOUZA JÚNIOR et al. (2010) and SANTOS et al. (2011) also found similarities between spatial variability pattern for physical and chemical soil properties and MS.

The $\mathrm{pH}, \mathrm{OM}, \mathrm{CEC}$ and MS attributes showed higher coefficients of determination $\left(\mathrm{R}^{2}\right)$, which were above 0.90 ; at both depths, indicating that $90 \%$ of spatial variability is explained by the adjusted model (Table 3 ) and the lowest $\mathrm{R}^{2}$ values were obtained for TS $(<78 \%)$. Concerning crossvalidation, we observed that all studied attributes at both depths obtained cross-validation regression coefficient (CVRC) near one for angular coefficient (b) and near zero for intercept (a), with the exception of CEC, TS and CLA at 0.60-0.80 m (Table 3).

Kriging maps allowed visualization of three distinct environments, corresponding to the three geomorphic surfaces (Figure 2). We observed that geomorphic surfaces coincide with compartments of controlled variability, indicating that soil attribute variability has spatial agreement with the boundaries among geomorphic surfaces in field. CAMPOS et al. (2007), SANTOS et al. 
(2011), and CAMPOS et al. (2012b) obtained similar results by studying soil chemical properties in different landscape compartments. DEMATTÊ et al. (2007), SANTOS et al. (2011), NOVAES FILHO et al. (2012) and CAMPOS et al. (2012b) highlight a numerical classification of models that take into account spatial distribution of soil attributes, to identify boundaries within soil taxonomic classes, and provide information on relationship between soil genesis and landscape evolution.

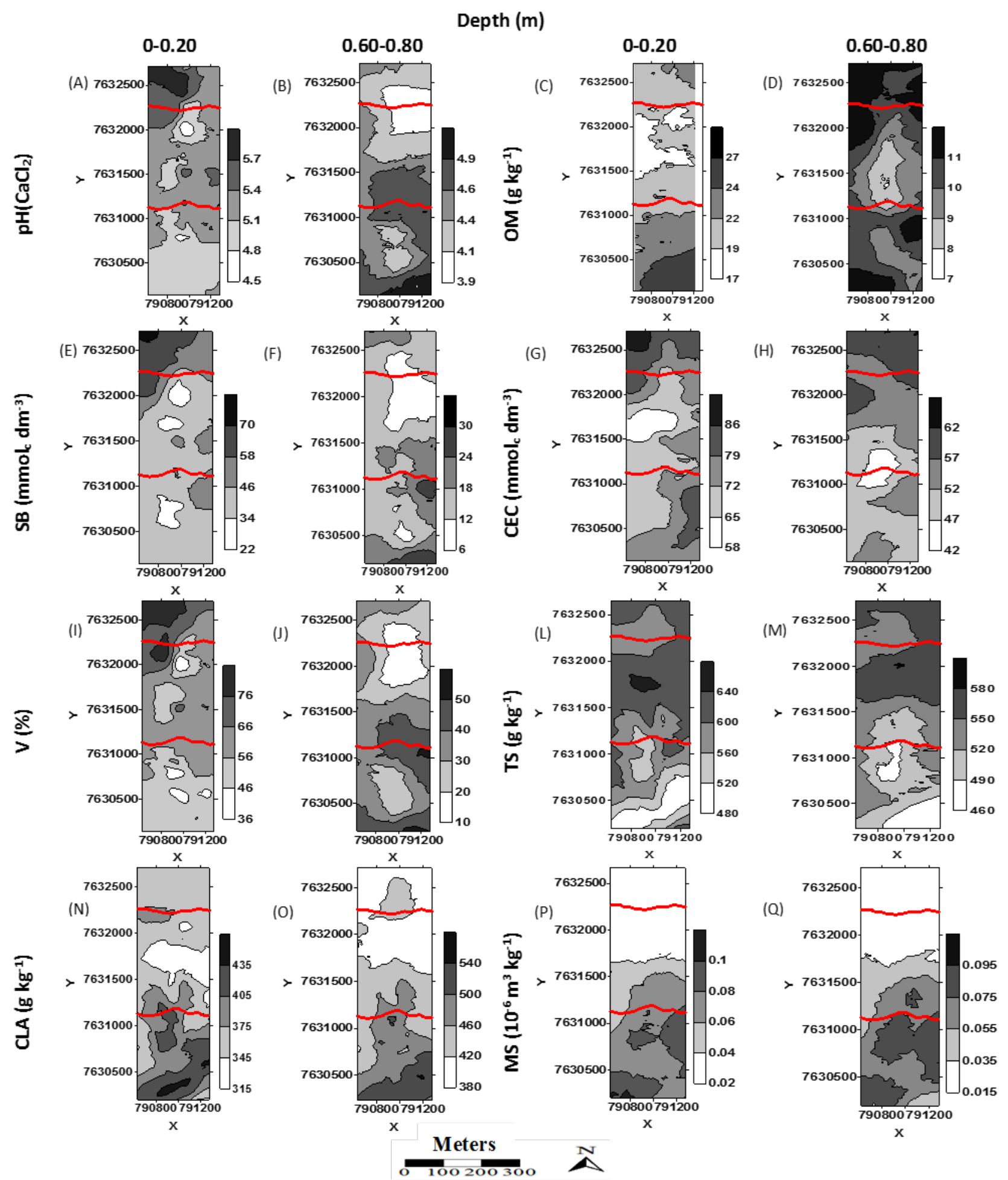

FIGURE 2. Spatial distribution maps for $\mathrm{pH}$ (A and B), organic matter (C and D), sum of bases (E and F), cation exchange capacity ( $\mathrm{G}$ and $\mathrm{H}$ ), saturation (I and J), total sand (L and M), clay ( $\mathrm{N}$ and $\mathrm{O}$ ) and magnetic susceptibility (P and $\mathrm{Q}$ ) at $0-0.20 \mathrm{~m}$ and $0.60-0.80 \mathrm{~m}$ depths. The red line indicates the geomorphic surface boundaries. 
Despite GS I is older and more weathered (Figure 2), it is the most homogeneous layer and has lower spatial variability than GS III, which is younger and with great heterogeneity (larger number of classes within same compartment), especially at 0.60-0.80 m depth. Thus, variability can be associated to soil formation factors and processes. What is supported by research developed by SANTOS et al. (2011) and CAMPOS et al. (2012a; 2012b), who also found greater variability of soil attributes in GS III.

Variability performance on TS, MS and CLA maps are consistent with concepts proposed by DANIELS et al. (1971), who showed decisive action of soil formation factors and processes. Moreover, we should highlight relief importance as it coordinates and directs water flow on soil profile and source material that interferes with chemical and physical soil behavior (NOVAES FILHO et al., 2012).

Studying the cause and effect of soil occurrence in different geomorphic surfaces, CAMPOS et al. (2007), SANTOS et al. (2011), and CAMPOS et al. (2012a) concluded that time and source material are responsible for spatial variability of soil attributes. Therefore, soil survey and detailed characterization of attribute spatial variability might become more accurate and less subjective when using geostatistical techniques and geomorphic surfaces models. Kriging maps inform spatial distribution of particle size and MS identify the boundaries among geomorphic surfaces; consequently aiding in specific management area delineation especially in sandstone-basalt transition areas. At these sites, soil homogeneity is based on coloration currently, so it can lead to misleading conclusions. Finally, interfering on agricultural planning, decision-making, experiment installation and case studies; or worse still, have an effect on crop responses and the environment in which they operate.

\section{CONCLUSIONS}

The identification of geomorphic surfaces allowed the definition of specific management areas with maximum homogeneity by means of soil attributes.

The spatial variability map of magnetic susceptibility can be used to validate precise boundaries among geomorphic surfaces in field and inferring on clay content and soil base saturation variability.

\section{REFERENCES}

BURROUGH, P.A., McDONNEL, R.A. Principles of geographical information systems. Oxford: University Press, 2000

CAMBARDELLA, C.A.; MOORMAN, T.B.; NOVAK, J.M.; PARKIN, T.B.; KARLEN, D.L.; TURCO, R.F.; KONOPKA, A. E. Field-scale variability of soil properties in Central Iowa Soils. Soil Science Society of American Journal, Madison, v.58, n.5, p. 1.501-1.511, 1994.

CAMPOS, M.C.C.; MARQUES JÚNIOR, J.; PEREIRA, G.T.; MONTANARI, R.; CAMARGO, L. A. Relações solo-paisagem em uma litosseqüência arenito-basalto na região de Pereira Barreto-SP. Revista Brasileira de Ciência do Solo, Viçosa, MG, v.31, n.3, p. 519-529, 2007.

CAMPOS, M.C.C.; MARQUES JÚNIOR, J.; PEREIRA, G.T.; SOUZA, Z.M.; MONTANARI, R. Planejamento agrícola e implantação de sistema de cultivo de cana-de-açúcar com auxílio de técnicas geoestatísticas. Revista Brasileira de Engenharia Agrícola e Ambiental, Campina Grande v.13, n.3, p.297-304, 2009.

CAMPOS, M.C.C.; RIBEIRO, M.R.; SOUZA JÚNIOR, V. S.; RIBEIRO FILHO, M.R.;

ALMEIDA, M.C. Relações solo-superfície geomórfica em uma topossequência várzea-terra firme na região de Humaitá (AM). Revista Brasileira de Ciência do solo, Viçosa, MG, v.36, p. 325-336, 2012a. 
CAMPOS, M.C.C.; MARQUES JÚNIOR, J.; SOUZA, Z.M.; SIQUEIRA, D.S.; PEREIRA, G.T. Discrimination of geomorphic surfaces with multivariate analysis of soil attributes in sandstone basalt lithosequence. Revista Ciência Agronômica, Fortaleza, v.43, n.3, p. 429-438, 2012b.

CANO, M.E.; CORDOVA-FRAGA, T.; SOSA, M.; BERNAL-ALVARADO, J.; BAFFA, O. Understanding the magnetic susceptibility measurements by using an analytical scale. European Journal of Physics, London, v.29, n.2. p. 345-354, 2008.

CUNHA, P.; MARQUES JÚNIOR, J.; CURI, N.; PEREIRA, G. T.; LEPSCH, I. F. Superfícies geomórficas e atributos de Latossolos em uma seqüência Arenítico-Basáltica da região de Jaboticabal (SP). Revista Brasileira de Ciência do Solo. Viçosa, MG, v.29, n.1, p. 81-90. 2005.

DANIELS, R. B.; GAMBLE, E. F.; CADY, J. G. The relation between geomorphology and soil morphology and genesis. Advances in Agronomy, San Diego, v. 23, n. 1, p. 51-87, 1971.

DEMATTÊ, J.A.M.; GALDOS, M.V.; GUIMARÃES, R.; GENÚ, A.M.; NANNI, M.R.; ZULLO JÚNIOR, J. Quantification of tropical soil attributes from ETM+/Landsat-7 data. International Journal of Remote Sensing, London, v. 8, n. 1, p. 3.813-3.829, 2007.

EMBRAPA - Empresa Brasileira de Pesquisa Agropecuária. Centro Nacional de Pesquisa de Solos. Manual de métodos de análise de solo. Rio de Janeiro, 1997. 212p.

IPT - Instituto de Pesquisas Tecnológicas do Estado de São Paulo. Mapa Geológico do Estado de São Paulo. São Paulo, 1981. v. 1. Escala 1:500.000.

MINITAB. Release making data analysis easier: version 13.1. 2000.

MONTANARI, R.; SOUZA, G.S.A.; PEREIRA, G.T.; MARQUES Junior, J.; SIQUEIRA, D.S.; Siqueira, G.M. . The use of scaled semivariograms to plan soil sampling in sugarcane fields. Precision Agriculture, Dordrecht, v. 13, p. 01-11, 2012.

NOVAES FILHO, J.P.; COUTO, E.G.; RODRIGUES, L.C.M.; CHIG, L.A.; JOHNSON, M.S. Indicativos de descontinuidade litológica de regolitos derivados de granitos em uma microbacia sob floresta amazônica, em Juruena - MT. Revista Brasileira de Ciência do solo, Viçosa, MG, v.36, p. 317-324, 2012.

OBI, J. C.; OGUNKUNLE, A. O. Influence of termite infestation on the spatial variability of soil properties in the Guinea savanna region of Nigeria. Geoderma, Amsterdam, v. 148, n. 1, p. 357363, 2009.

RAIJ, B. Van.; ANDRADE, J.C.; CANTARELLA, H.; QUAGGIO, J.A. Análise química para avaliação da fertilidade de solos tropicais. Campinas: Instituto Agronômico, 2001. 284p.

ROBERTSON, G. P. GS ${ }^{+}$: geostatistics for the environmental sciences (version 9 for windows). Gamma Design Software, 2008. 179p.

ROSA FILHO, G.; CARVALHO, M.P.; ANDREOTTI, M.; MONTANARI, R.; BIONOTTI, F.F. S.; GIOIA, M.T. Variabilidade da produtividade da soja em função de atributos físicos de um latossolo vermelho distroférrico sob plantio direto. Revista Brasileira de Ciência do Solo, Viçosa, MG, v.33, p.283-293, 2009.

ROCKSTROM, J.A. Safe operating space for humanity. Revista Nature, v. 461, p. 472 - 475, 2009. RUHE, R. V. Quaternary landscape in Iowa Ames. Iowa: State University Press, 1969. 255p.

SAS. Statistical Analysis System for Windows: computer program manual. Cary, 2007.

SANCHEZ. R.B.; MARQUES JÚNIOR. J.; SOUZA. Z.M. de. Variabilidade espacial de atributos do solo e de fatores de erosão em diferentes pedoformas. Bragantia, Campinas, v.68, n.4, p.10951103, 2009. 
SANCHEZ, R.B.; MARQUES JÚNIOR, J.; PEREIRA, G.T.; BARACAT NETO, J.; SIQUEIRA, D.S.; SOUZA, Z.M. Mapeamento das formas do relevo para estimativa de custos de fertilização em cana-de-açúcar. Engenharia Agricola, Jaboticabal, v.32, n.2, p.280-292, mar./abr. 2012.

SANTOS, H.L.; MARQUES JÚNIOR, J.; MATIAS, S.S.R.; SIQUEIRA, D.S.; PEREIRA, G.T. Suscetibilidade magnética na identificação de compartimentos da paisagem em uma vertente. Revista Brasileira de Ciências Agrárias, Recife, v.6, n.4, p.710-716, 2011.

SIQUEIRA, D.S., MARQUES JÚNIOR, J., PEREIRA, G.T. The use of landforms to predict the variability of soil and orange attributes. Geoderma, Amsterdam, v.155, p. 55-66, 2010a.

SIQUEIRA, D.S.; MARQUES JÚNIOR, J.; MATIAS, S.S.R.; BARRÓN, V.; TORRENT, J.; BAFFA, O.; OLIVEIRA, L.C. Correlation of properties of Brazilian Haplustalfs with magnetic susceptibility measurements. Soil, Use and Management, Oxford, v.26, n.4, p. 425-431, 2010b.

SOUZA JUNIOR, I.G. SOUZA JUNIOR, I.G.; COSTA, A.C.S.; VILAR, C.C.; HOESPERS, A. Mineralogia e susceptibilidade magnética dos óxidos de ferro do horizonte B de solos do Estado do Paraná. Ciência Rural, Santa Maria, v.40, n.3, p.513-519, mar, 2010.

SURFER for windows. Realese 8.0. Contouring and 3D surface mapping for scientist's engineers. User's Guide. New York: Golden software, 2000.

TORRENT, J., LIU, Q.S., BLOEMENDAL, J., BARRO' N.V. Magnetic enhancement and iron oxides in the upper Luochuan loess- paleosol sequence, Chinese Loess Plateau. Soil Science Society of America Journal, Madison, v.71, p. 1-9, 2007.

TORRENT J., BARRON V., LIU Q. S. Magnetic susceptibility changes in relation to pedogenesis in a Xeralf chronosequence in northwestern Spain. Geophysical Research Letters, Washington, v. 61 p. 161-173, 2010.

VIDAL-TORRADO, P.; LEPSCH, I. F.; CASTRO, S. S. Conceitos e Aplicações das Relações Pedologia Geomorfologia em Regiões Tropicais Úmidas. In: P. Vidal-Torrado; FERRACIU, L. R.; COOPER, M.; CARDOSO, E. J.; PROCHONOW, L.I., (Org.). Tópicos em ciência do solo. Viçosa: Sociedade Brasileira de Ciência do Solo, 2005. v. 4, p. 145-192.

YAMAMOTO, J. K.; LANDIM, P. M. B. Geoestatística conceitos e aplicações. São Paulo: Editora Oficina de Textos, 2013. 216p,

WARRICK, A. W.; NIELSEN, D. R. Spatial variability of soil physical properties in the field. In: HILLEL, D. (Ed.). Applications of soil physics. New York: Academic Press, 1980. cap. 2, p. 319344.

WEBSTER, R. Automatic soil-boundary location from transect data. Math. Geology, Boulder, v. 5, p. 27-37, 1973. 